\title{
The relationship between organizational justice and
} organizational citizenaship behavior practice with the sports specialiat in Alexandria university youth wellfare administrations

\section{"Dr/ Rehab Aly Amin \\ *** Dr /Reham Amin Hamzah}

Research problem and importance:

The organizational justice is a major subject has the organization's interest which work efficiencly, we can see The organizational justice as one of the important organizational variables, which has the Probable on the employees functional performance efficiency -in a side- and the organization 's performance - in the other side.

The organizational justice is considered a relative concept, in other words the organizational procedureswhich any one may see it as a justice procedure - may be unfair procedure from another one 's sight, so The organizational justice is determined in the high light of what can any one understand related to procedures and outputs Impartiality and objectivity.( 3:12) (41:530528)

Both of Omar Dorrah (2008) , Alaa Mohamed Sayed (2010) agreed that : the citizenship behavior represents acts Trespassing Within the functional duties and burdens, and over all Formally described in the organization or beyond the official roles.(23:16), (4:19)

Kalleberg et al(2004) define it as an individual behavior distuiguished, Not be appreciated by the official reward systems in the Organization which enhance effective organization functions entirely.(40:6)

Scientists and writers agree on defining organizational citizenship here: Altruism, kindness and

Assisstant. Pro .in the Department of Sports Management, Faculty of physical Education for Girls, Alexandria University.

A Lecturer in the Department of Sports Management, Faculty of physical Education for Girls, Alexandria University 
courtesy, sportsmanship, conscience, (35:4),(43:110),(42:26)

Both of the two researchers reached the search problem through supervising of the third \&fourth (Sports management branch)students During the participation of female students in numerous competitions and sports activity management activities at the University of Alexandria, so they recognized:

Reduced sense of organizational justice sports specialists, The dissatisfaction of employees from the current system of evaluation

Through the pilot study in which the two researchers has carried put on a sample of(11)items, thrier distribution was as follow, to recognize The Relationship between Organizational Justice and Organizational Citizenaship Behavior with the sports specialiat in Alexandria University Youth wellfare Administrations (Appendix 1)

The opinions of all statement was negative, confirming that there is nojustice in the funcyional tasks didtribution, a Lack of a unified system, not to participate in solving problems.

Throw revision of many previous studies, such as Hian Hemdan Study (2015) (13), Barzan Saber Hussien (2014) (8), Mohamed Abdulhameid etal (2015) (15) , Hamzah Moaamary Bin Zahy Mansour (2014) (12), Nazik Moustafa Sombol, Yousriya Ibraheim Moussa (2008) (21), Yousriya Ibraheim Moussa (2007) (32), Said Shaaban Hamed (2010) (11), Mohamed Abdulateif Khaleifah (2009) (14), Yasser Fathy Alhendawy Almahdy (2006) (31), Gill and, S.,Benson, et al (2008) (38), Omar Mohamed Ahmed Awaad (2003) (22), Amer Aly Hussien Alatawy (2007) (6) A strong correlation between the independent variable function of citizenship and the dependent variable improve performance, Citizenship performance wellfare contributes to improving organizational effectiveness, There is a link between organizational justice and organizational citizenship behavior, Organizational justice is linked to all of the performance appraisal systems and pay satisfaction. 
In the hight of the above mentioned the two researcher has established the research problem titled:

The

Relationship between Organizational Justice and Organizational Citizenaship Behavior Practice with the sports specialiat in Alexandria University Youth wellfare Administrations

\section{The research aim:}

The research aims to recognize The Relationship between Organizational Justice and Organizational Citizenaship Behavior Practice with the sports specialiat in Alexandria University Youth wellfare Administrations through:

1- Identify the dimensions

of organizational Justice (distributive justice, procedural justice, fairness, personal transactions)

2- Identify the dimensions of organizational citizenship behavior (altruism, kindness and courtesy, sportsmanship, conscience, civilly).

3- Determine the relationship between organizational justice and organizational citizenship behaviors

\section{The research procedures:}

The method: The discribtive survey

The sample: Total sample research (132) of the total sample of research number (183) representing by departments managers (17), sports specialist in Alexandria University Youth wellfare Administrations (115)

\section{Data collection tools:}

- $\quad$ A pilot study (Annex 1)

- The scale Scientific

Transactions: 
First: The scale validity:

A- Coefficient of internal consistency of the scale

Table (1)

the consistency factor correlation degree phrase total dimension

belonging to $n=26$

\begin{tabular}{|c|c|c|c|c|c|c|c|c|c|c|c|}
\hline Dimensions & $\begin{array}{c}\text { The } \\
\text { word } \\
\text { number }\end{array}$ & $\begin{array}{l}\text { Consistency } \\
\text { Coefficient }\end{array}$ & Dimensions & $\begin{array}{c}\text { The } \\
\text { word } \\
\text { number }\end{array}$ & $\begin{array}{l}\text { Consistency } \\
\text { Coefficient }\end{array}$ & Dimensions & $\begin{array}{c}\text { The } \\
\text { word } \\
\text { number }\end{array}$ & $\begin{array}{l}\text { Consistency } \\
\text { Coefficient }\end{array}$ & Dimensions & $\begin{array}{c}\text { The } \\
\text { word } \\
\text { number }\end{array}$ & $\begin{array}{l}\text { Consistency } \\
\text { Coefficient }\end{array}$ \\
\hline \multicolumn{3}{|c|}{$\begin{array}{l}\text { The first axis } \\
\text { (organizational justice:) }\end{array}$} & $\begin{array}{l}\text { The first axis } \\
\text { :(organizational }\end{array}$ & 19 & $\begin{array}{l}\text { The first axis : } \\
\text { (organizatio }\end{array}$ & $\begin{array}{l}\text { B - Kindness } \\
\text { and civility : }\end{array}$ & rA & $* * \cdot, y .0$ & \multirow{12}{*}{$\begin{array}{l}\text { D-aware } \\
\text { conscience. } \\
\text { conscience. }\end{array}$} & $42 / 1$ & $* * .010$ \\
\hline \multirow{7}{*}{$\begin{array}{l}\text { A Justice of } \\
\text { distributions: }\end{array}$} & , & **. T & & $19 / 1$ & $* * \cdot, T \leqslant r$ & & rq & $* * .7 \mathrm{TV}$ & & $42 / 2$ & $* *, 710$ \\
\hline & r & $* * .709$ & & $19 / 2$ & $* *$. TrV & & $r$. & $* *$. yoo & & $42 / 3$ & $* *, v \cdot v$ \\
\hline & $r$ & $* * . T T V$ & & $19 / 3$ & **. $.09 \varepsilon$ & & $r$ & $* * . .01 \wedge$ & & $42 / 4$ & $* *, Y Y Y$ \\
\hline & $\varepsilon$ & $* * .0 \times 4$ & & $19 / 4$ & $* * .700$ & & rt & $* * \cdot, v r \leqslant$ & & $42 / 5$ & $* * ., 7 \mathrm{~V}$ \\
\hline & 。 & $* *$. TVV & & r. & **. & & $r r$ & **. yro & & $42 / 6$ & $* * ., T r$ \\
\hline & 1 & $* * . .700$ & & $r$ & $* * \cdot, Y \wedge$ & & $r \xi$ & $* * . .090$ & & $42 / 7$ & $* * ., y \cdot 0$ \\
\hline & v & **., y. o & & rr & **. .094 & & ro & $* * .7 \mathrm{VY}$ & & $42 / 8$ & $* * . .091$ \\
\hline & $\wedge$ & $* * .0 \wedge \leqslant$ & & $r$ & **. Trv & & rs & $* * .7 \%$. & & $42 / 9$ & $* *$. TVo \\
\hline & 9 & $* * .7 \pi \leqslant$ & \multicolumn{3}{|c|}{ The second axis (citizenship) } & & rv & $* * .7 \times 9$ & & $42 / 10$ & $* * \cdot 7 \leqslant 1$ \\
\hline & 1. & $* * .7 V 1$ & & $r \xi$ & $* *$. TV. & & $r_{\Lambda}$ & $* * .700$ & & $42 / 11$ & $* * . .09$ \\
\hline & 11 & $* * . .091$ & & ro & $* * .70 \mathrm{y}$ & & ra & **. vro & & $\leqslant$ & $* * .7+9$ \\
\hline & ir & **. & & r & **. . ०ท9 & & 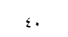 & $0.726^{* *}$ & \multirow{6}{*}{$\begin{array}{l}\text { Civilized } \\
\text { behaviour }\end{array}$} & $\vdots$ & \\
\hline & ir & $* * .0 \wedge \leqslant$ & & $r v$ & & & ؛ & & & $44 / 1$ & $* * .7 \leq$ \\
\hline & $1 \leqslant$ & $* * \cdot, 7 \leqslant r$ & & $27 / 1$ & $* * .09 \mathrm{y}$ & & $41 / 1$ & $* * \cdot, y \cdot \wedge$ & & $44 / 2$ & $* * . .109$ \\
\hline & 10 & $* * .794$ & & $27 / 2$ & $* * .0 \times 7$ & & $41 / 2$ & $* *$. Y) & & $44 / 3$ & $* * . \pi r$ \\
\hline \multirow{3}{*}{$\begin{array}{c}\text { B-procedural } \\
\text { fairness: }\end{array}$} & 17 & **. OVY & & $27 / 3$ & $* * \cdot v \cdot q$ & & $41 / 3$ & $* * .7 T r$ & & $44 / 4$ & $* * . v \vee r$ \\
\hline & iv & $* * ., 7 \pi$ & & $27 / 4$ & $* *$. Trr & Sportsmanship & $41 / 4$ & $* * .017$ & & $44 / 5$ & $* * \cdot v \cdot 1$ \\
\hline & « & **. .09Y & A altruism & $27 / 5$ & **. ITr & & $\leqslant r$ & & & & \\
\hline
\end{tabular}

* Significant with $0,05=0,38 * *$ Significant with $0,01=0,487$

Assiut Journal For Sport Science Arts 
Table (2)

internal consistency coefficient correlation dimension degree total

axis $n=26$

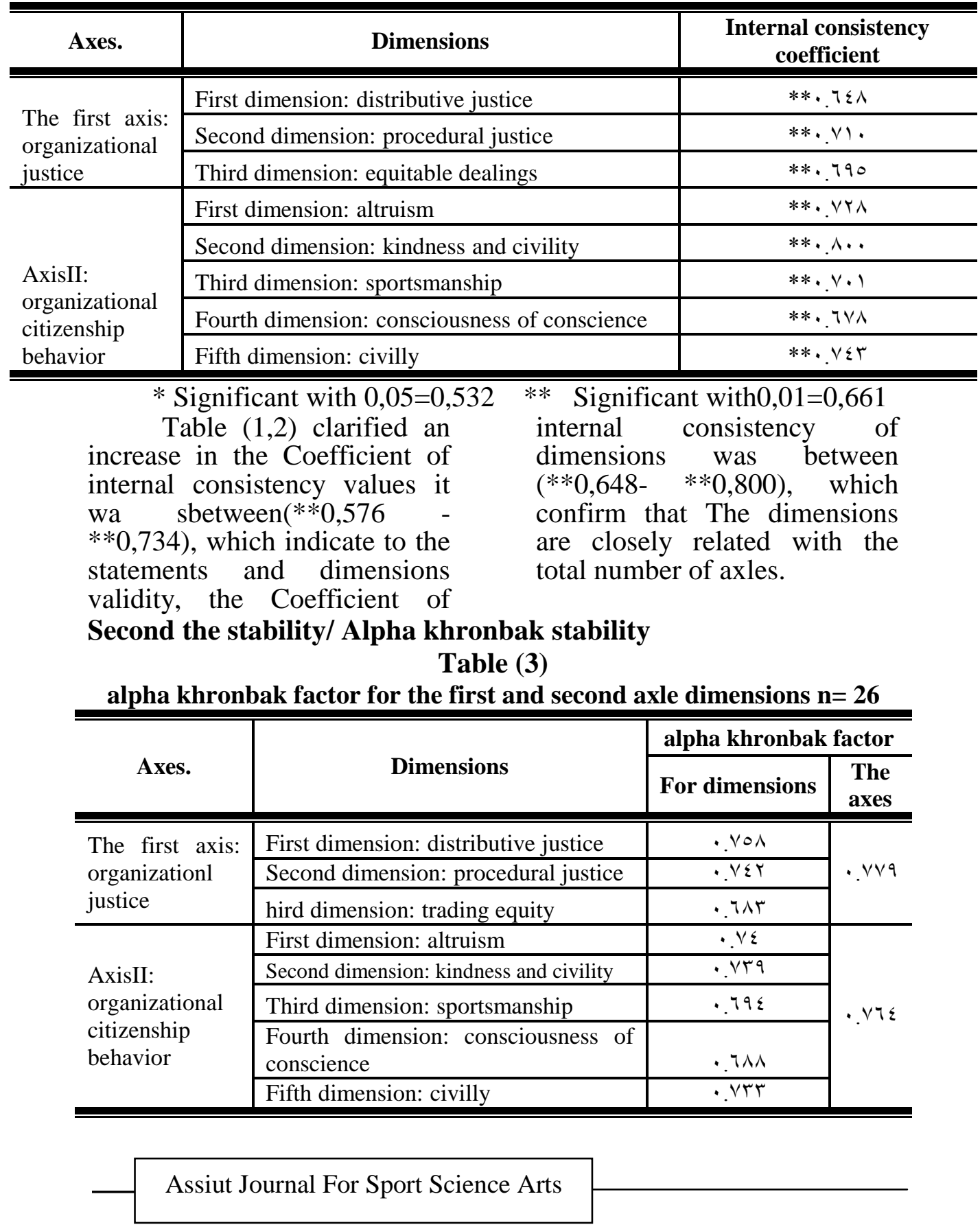


illustrated by table (3) high alpha khronbak factor greater than 0.600 which confirms that the dimensions Homogeneous and are conservative The statistical transactions
We utilized the appropriated transactions for the research nature

The results duscussions:

First: The first axis dimensions results"the organizational justice"

\section{Table (4)}

approval of the first axis dimensions: organizational Justice (first dimension: distributive justice) $n=132$

\begin{tabular}{|c|c|c|c|c|c|c|c|c|c|c|c|c|c|c|c|c|c|c|}
\hline \multirow[b]{2}{*}{$\begin{array}{l}\text { Statement } \\
\mathrm{N}\end{array}$} & \multicolumn{6}{|c|}{ Sports Specialist Group $\mathrm{n}=115$} & \multicolumn{6}{|c|}{ Youth welfare departments managers $\mathrm{N}=12$} & \multicolumn{6}{|c|}{ Total Research Group N=132 } \\
\hline & Yes & fairly & No & Q2 & $\begin{array}{l}\text { The } \\
\text { Mean }\end{array}$ & $\begin{array}{l}\text { The } \\
\text { approval } \\
\text { rate }\end{array}$ & Yes & fairly & NO & Q2 & $\begin{array}{l}\text { The } \\
\text { Mean }\end{array}$ & $\begin{array}{l}\text { The } \\
\text { approval } \\
\text { rate }\end{array}$ & Yes & fairly & NO & $\begin{array}{l}\text { The } \\
\text { approval } \\
\text { rate }\end{array}$ & $\begin{array}{l}\text { The } \\
\text { Mean }\end{array}$ & $\begin{array}{l}\text { Q2 for } \\
\text { the two } \\
\text { classes } \\
\text { approval } \\
\text { rate }\end{array}$ \\
\hline 1 & r & v & 9 & ( & (1) & (Y) & 9 & $\therefore$ & Y & 世 & Y & ra & $\mathrm{rat}$ & r & & ( & (1) & * \\
\hline Tr & & & & & & & & & & & & & & & & & & \\
\hline & $\leqslant r$ & ir & 7. & $*$ * १, r & $1 . \wedge \varepsilon$ & 71.0 & 11 & 。 & 1 & $* \wedge, 9 \leqslant$ & $r .09$ & 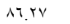 & or & is & 11 & $7 \leqslant .70$ & 1.95 & $* \xi .1 \mathrm{\gamma}$ \\
\hline$r$ & r. & $\mathrm{v}$ & 11 & $* 9 \lambda, v r$ & $1 . \leqslant 1$ & $\leqslant 7.97$ & $\mathrm{v}$ & A & r & $r .70$ & r. ז9 & $\mathrm{V} \uparrow . \mathrm{V}$ & TV & 10 & 9. & $0.1 \mathrm{~V}$ & 1.04 & $* v_{.} .7$ \\
\hline ؛ & 04 & 19 & 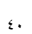 & $* 1 \vee .9 \vee$ & r.) & vi.r & 7 & 1. & 1 & $* \mathrm{v} .1 \mathrm{~A}$ & r. rq & $\mathrm{V}, \leqslant \mathrm{V}$ & זיד & rq & @) & $v 1.9 \mathrm{y}$ & 5.17 & .11 \\
\hline o & rA & 7 & 1) & $* \mathrm{~V}$ Y.00 & $1.0 \leqslant$ & $01 . r$ & 11 & $\varepsilon$ & r & $* \vee, \wedge \Lambda$ & r.or & $\lambda \leqslant, r)$ & rq & 1. & NT & 00.07 & $1.7 \mathrm{~V}$ & $* \lambda . r$ \\
\hline 7 & 1 & r & QY & $* 111.0$ & $1 . r 1$ & $\leq .+9$ & IT & 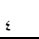 & 1 & $* 11 . \leqslant 1$ & $r .70$ & $M_{,}, Y \leqslant$ & 15 & rq & 95 & $\leqslant 7 . \leqslant 7$ & $1 . r 9$ & $* 1$ *.८9 \\
\hline v & rq & ri & ؛ & r.OV $\leqslant$ & 1.90 & $7 \leqslant .94$ & 0 & 1. & $r$ & 0.17 & $r .1 A$ & $V Y .00$ & $\llbracket £$ & § & $\leqslant v$ & 70.91 & 1.91 & $\cdot \leq r$ \\
\hline
\end{tabular}

$* \mathrm{q}_{2}$ Significant with $0,05=5,99$

Shown in the table (4) opposes the sports specialists and departments managers of the youth wellfare for the statements number $(1,3,5,6)$, $\mathrm{q}_{2}$ value clarified the approval rate for the two classes was between $(* 6,01-* 17,89)$ the sports specialists opinions has a low approval rate, was between $(* 40,29-52,17 \%)$, the departments managers opinions has a High approval rate was between $(76,47$ $88,24 \%$ ) That burden and are not distributed equitably functions, Not taking into account the skills and desires of sports specialists, Not to get

incentives and rewards to achieve contentment

This is consistent with the results of each study: Shaimaa Mohamed Gaber(2014) (29), Donia Mohamed Adel (2001) (9) Rabein Hamad Rassoul (2014) (24) Where has proved that the Division of work within the Youth wellfare Department University of Alexandria is not justice and equality, Both of Youssif Eid Atteia Bahr, Ayman Soliman Abou Sweirah (2010) (33), Mohamed Ngeib Mahmoud (2004) (16) recommended The necessity of a Material or moral incentives to motivate 
athletes specialists work done as efficiently as possible.

The two researchers believe in the light of the statistical results that there is unfairness in distribution of different administrative levels s[prts specialists manage physical activity according to their qualifications and reflected on the nature of their tasks

While the opinions of respondents on the statement (2) by consent $(61.45 \%)$ for the sports specialists, While the youth wellfare departments managers responses by consent $(86.27 \%) \mathrm{q}_{2}$ for the approval rate for the two classes was $(* 4,17)$ which clarify that There is justice in the distribution of the different administrative levels athletes specialists according to their qualifications, which was confirmed by both of Mohamed Nageib Sabry (2004) (17) Mahmoud Abdulrahman Ibraheim (2006) (14) , Omar Mohamed Dorrah confirms (2009) that There is a mismatch of the nature, functions and duties of the jobs held with employees qualifications and disciplines licensees. (23:35)

The two researchers believe that Perception and a sense that athletes specialists there is justice in the promotion system followed by the youth wellfare departments of the University of Alexandria to affect their behaviours

Table (5)

approval of the first axis dimensions: organizational Justice (second dimension: procedural justice) $\mathrm{n}=132$

\begin{tabular}{|c|c|c|c|c|c|c|c|c|c|c|c|c|c|c|c|c|c|c|}
\hline \multirow[b]{2}{*}{$\begin{array}{l}\text { Statement } \\
\mathrm{N}\end{array}$} & \multicolumn{6}{|c|}{ Sports Specialist Group $n=115$} & \multicolumn{6}{|c|}{ Youth welfaredepartments managersN=17 } & \multicolumn{6}{|c|}{ Total Research Group N=132 } \\
\hline & Yes & fairly & No & $\mathrm{q}_{2}$ & $\begin{array}{l}\text { The } \\
\text { mean }\end{array}$ & $\begin{array}{l}\text { The } \\
\text { approval } \\
\text { rate }\end{array}$ & Yes & fairly & No & Q2 & $\begin{array}{l}\text { The } \\
\text { mean }\end{array}$ & $\begin{array}{l}\text { The } \\
\text { approval } \\
\text { rate }\end{array}$ & Yes & fairly & No & $\begin{array}{l}\text { The } \\
\text { approval } \\
\text { rate }\end{array}$ & $\begin{array}{l}\text { The } \\
\text { mean }\end{array}$ & $\begin{array}{l}\mathrm{q}_{2} \text { for } \\
\text { the two } \\
\text { classes } \\
\text { approval } \\
\text { rate }\end{array}$ \\
\hline 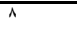 & rI & $\mu$ & 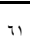 & *Y, qA & 170 & $00 . v$ & r & 7 & 9 & $\leqslant r_{0}$ & 109 & or 98 & $r$ & $r q$ & v. & $0 \leqslant 1$ & 174 & $\ldots$ \\
\hline 9 & rq & A. & 1 & $* v \varepsilon, \lambda r$ & r.t & קetr & ir & 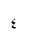 & . & $* 10.70$ & r.vi & 97.17 & $\leqslant r$ & גई & 7 & yo,y & t.ti & ri! \\
\hline 1. & ri & $\leqslant 0$ & ६१ & $* 11.9 \mathrm{r}$ & 1.17 & 01.00 & v & $\wedge$ & r & $r .70$ & r.rq & $\mathrm{V}_{7} \leqslant \mathrm{~V}$ & rA & or & 01 & $7 . \wedge \pi$ & $1 . \Delta r$ & r.rA \\
\hline$" 1$ & . & rq & A & *VA, Yo & $1, r \xi$ & צ & v & q & 1 & $* 1, i r$ & r.ro & $V_{\lambda} \leqslant r$ & ir & $r_{\lambda}$ & Ar & «৯.११ & $1 . \varepsilon \mathrm{V}$ & $* q$, , \\
\hline 14 & i. & Ir & ar & $* \| \mathrm{V}$ & I.YA & $\varepsilon r, \pi$ & ir & $r$ & , & $* 1 \leqslant .09$ & $r(v)$ & Q.. & rT & 10 & १ะ & 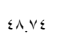 & 1.87 & $* i v . .0$ \\
\hline it & $\wedge$ & 11 & 97 & $* 1+r . r$ & irr & $\$ 1,17$ & $\lambda$ & ^ & , & $0 . Y^{\prime}$ & r. & A.rq & 17 & 19 & av & st.r & $1, r q$ & HוT \\
\hline $1:$ & ir & $m$ & rr & $* \leqslant 9.9$ & $1 \leqslant \wedge$ & $\varepsilon १, ५ \wedge$ & ir & 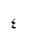 & , & $* 11 \leqslant 1$ & $r .90$ & Aג, rs & rs & ro & vr & $0 \leqslant . r q$ & $1.7 \%$ & $* 11 . . \leqslant$ \\
\hline 10 & 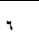 & r. & vq & *VYYY & irv & $\{0,01$ & $\lambda$ & 9 &. & $* \wedge \circ 9$ & $r \leqslant Y$ & Arro & $1 \leqslant$ & rq & vq & $0 . r_{0}$ & 1.01 & $* 1 . \pi$ \\
\hline 19 & v & rq & $v \xi$ & $* 09$ r & $1 \leq r$ & $\leqslant y r_{0}$ & r & 。 & $\therefore$ & Ty & 1or & 0.91 & 9 & ra & $\Lambda \xi$ & $\varepsilon v \psi r$ & $1 \leqslant r$ & $.1 \xi$ \\
\hline iv & $1:$ & 10 & $\Delta$ & $* \Delta \Lambda \mathrm{qr}$ & i ry & $\varepsilon_{0} \wedge$ & 10 & r & 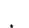 & $* r \leqslant 1$ & $r \Delta \Lambda$ & $97 . A$ & rq & iv & AT & or YY & $10 \%$ & *lyar \\
\hline 11 & $r$ & 01 & ri & r & r..r & $T Y Y_{0}$ & 1 & 1 & 1. & $* Y, 1 A$ & $1 \leqslant \xi Y$ & $\varepsilon 9 . . r$ & $r \xi$ & or & $\S$ & $7 \leqslant .9$ & 1.90 & $r . \wedge T$ \\
\hline
\end{tabular}

Q2 significant WITH $0,05=5,44$ 
Shown in table (5) lack of differences between categories of searches on phrases numbers $(8,9,10,16$, 18) Where the average College approvals came between (47.73:64.90\%) and squared value for percentage of approval categories (0.04:2.86) the absence of a standardized and fair performance evaluation, Failure to follow specific steps to make decisions without bias procedures against decisions, not having the freedom to choose how to implement, as individual replacement policy methodology does not behave elsewhere.

Abdulkarim Saleh Alsokar study (2013) (1) recommend: to Work on laying the foundations for procedural fairness because of procedural justice effect on job performance of employees.

The two researchers believe that it is the functionality of emp;oyees within the framework of the rules of procedure and regularity that helps to accomplish a business make career is within assessment. indicated by phrases $(11,12,13,14,15,17)$ differing views of the search categories with approvals for sports specialists between (41.16:49.28\%) While the directors approval rate came between (78.43:90.77\%) Squared value where it came to the groups between approval percentage $(9.28 *$ : $17.82 *)$ included the Director's eagerness to show each employee opinion before making decisions,

There is justice in nominating sports specialists for specialists training courses, all proposals are put into consideration the subordinates, the Director explains the decisions and discusses the consequences of those decisions, follow a unified system of sanctions within the work.

Both of Amin Abdul Aziz Hasan (2001)(7), Mohammed Ahmed Yunis study results (2009) (19), Hakem Muhsin Muhammad al-rabeei, haidrhamodi (2009) (10), Gillil \&, S, Benson (2008) (39) is not confirm that pursuing a policy of reward and punishment on the first stage of the youth welfare departments, Alexandria University $(7: 77)$ The two researchers believe that That sense of fairness 
workers depends very much on the ability of managers to achieve the kind of effective communication between them

Table (6)

and professionals through the Director's eagerness to show each employee opinion before making decisions.

\section{consent to terms first axis dimensions: organizational Justice}

(third dimension: Justice personal interactions) $\mathbf{n}=132$

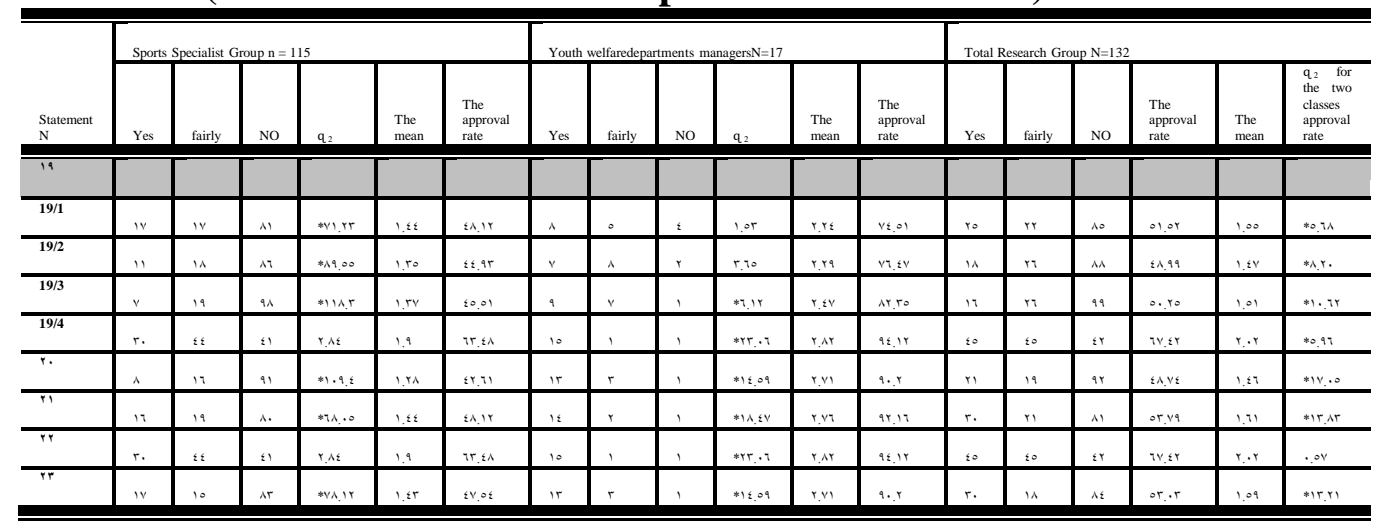

q 2 significant WITH $0,05=25,44$

Illustrated by table (6) moral differences between the responses of all search categories except for ferries ferry (22), where pherases (19/1, 19/2, 19/3, 19/4, 20, 21, 23) approval for sports specialists between (42.61:63.48\%) and for directors (74.51:98.78\%) Q2value of the groups's approval rate $(5.68 *$ : $17.05 *)$ included to account manager when making a decision to be discussed with the utmost frankness, taking into consideration personal demands for specialists, treating them with respect and attention, and help them to perform their work, using a standard policy in dealing with all individuals.

While the pherase (22) each agreement describes two categories on the lack of fairness in dealing with complaints and grievances by consent of faculty (49.49\%) And KA2value (0.57)

Study results indicate of Podsakoff (2002) (43), Gary Dessler (2005) that the sense of personal trading justice employees due to their confidence in the Commander. $(37: 529)$ 
The two researcher feel the need to take into account follow the principle of equality in dealing with all sports specialists
Second: results of the second axis dimensions: citizenship behavior

Table (7)

percentage of approval of the second axis dimensions: citizenship Behavior (first dimension: altruism) $n=132$

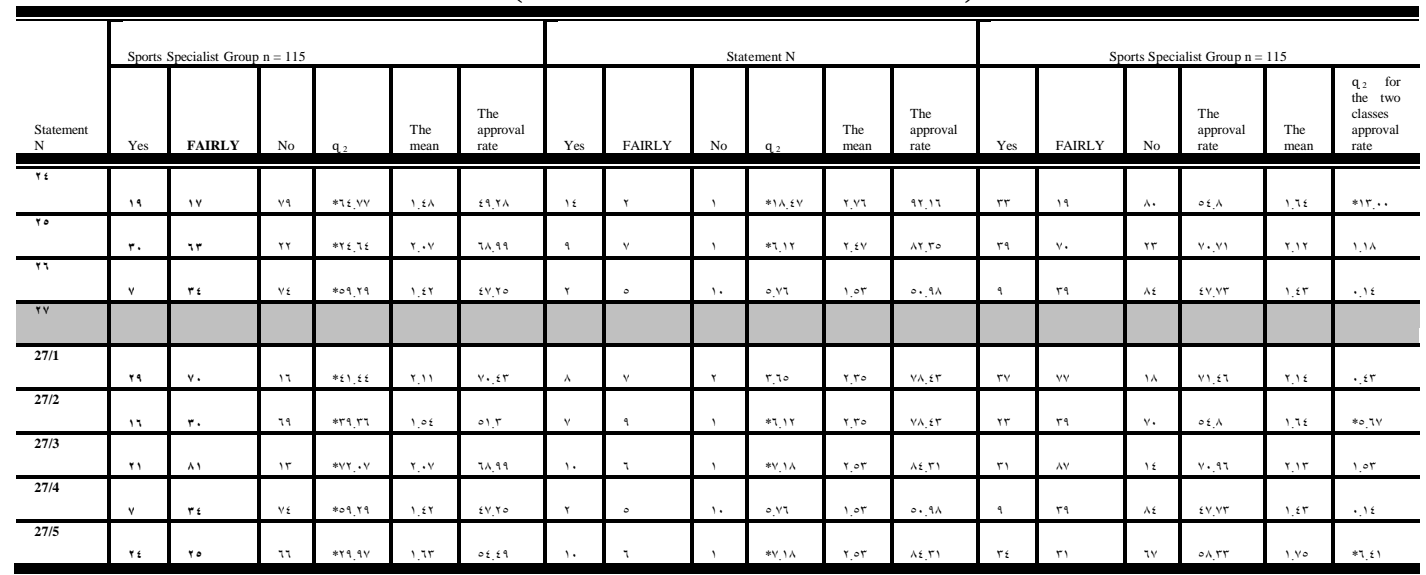

q 2 significant in .,05=5,44

Shown in table (7) moral differences between search categories responses for phrases numbers $(24,27 / 2$, 27/5) where sports specialists ' opinions came down by low approval between (49.28:54.49\%) High approval rate and the directors between (78.43:91\%) That specialist helps athletes each other when performing different jobs, volunteering to help their colleagues in excess burden, subtract an additional functional time outside the formal needs time to work.

Yilmaz , K. \&Tasdan, M (2008)indicate that altruistic behavior is intended to help people accomplish tasks within organizational work. (44:108) the two researchers said that citizenship is an optional behaviors of sports specialists, and youth welfare departments managers beyond the officially selected job.

While consensus about phrases $(25,27 / 1,27 / 3)$ by consent between College Research Group (70.96:71.46\%) Indicate nonfrequency specialists give colleagues information and experience to business 
performance, volunteer to help their colleagues in case of their absence from work, and facilitate new colleagues.

The results of Rajab Hussein Rifai study (2004) (25) confirms that the behavior of altruistic behavior is beyond functional duties and burdens.

The two researchers believes that altruism is one of the most important aspects of citizenship for youth welfare departments, University of Alexandria, which has the effect of a positive functional performance.

As the sample agreed search phrases about low numbers $(26,27 / 4)$, total research group approval rate came $\quad(47.73 \%)$ Phrases associated with unwillingness of specialists, athletes to work extra hours voluntarily, not to participate in solving problemsThe results of both of Safaa Mohamed Ammar, Nawal Mahmoud Alnady (2013) (27) confirm that there should be cooperation between the superiors and colleagues and facilitate solve problems and difficulties within the work because it is one of the characteristics organizational citizenship.

The two researchers believe that the nature of work within the Department of youth and the type of relationships and interactions among sports specialists have a significant role in the success and achievement of objectives within the Department which contributes to increase sports specialists to make a lot of giving and effort

Table (8)

the approval rate of the second axis dimensions phrases: citizenship behavior (second dimension: kindness and civility)

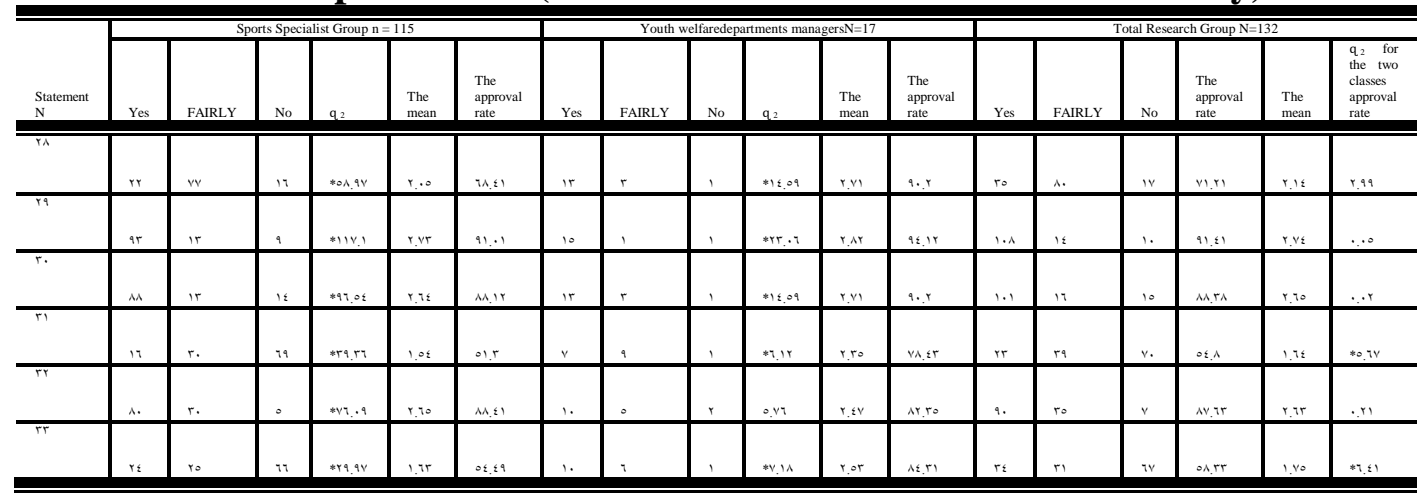

$\mathrm{q}_{2}$ significant in .,05=5,44 
Illustrated by table (8) consensus among respondents about the second dimension expressions involving numbers $(28,29,30,32)$ where $q_{2}$ value of approval categories $(0.02: 2.99)$ where the focus is more on the positive aspects of the negative aspects, magnified the problems facing the management of sporting activity, the sports specialist tolerates any personal abuse, accepting constructive criticism.

llustrated by phrases numbers $(31,33)$ search categories have different views with approval percentage of youth welfare departments managers (78.43,
$84.31 \%)$ And specialists to deny it $(51.3,54.49 \%$ that don't tolerate frustrating situations for employees and preventing goals and nitpick that issued by colleagues

The results of Shaaban Hussein Sisi (2005) (28) study confirm that individual skill from carrying positions without complaint leads to focus on colleagues and leaders achieve goals. The two researchers believe that the desire of sports specialists in tolerance and their ability to handle problems and overcome difficult tasks contributes to the development of performance and organizational effectiveness.

\section{Table (9)}

approval of the second axis dimensions: the third dimension:

sportsmanship $\mathrm{n}=\mathbf{1 3 2}$

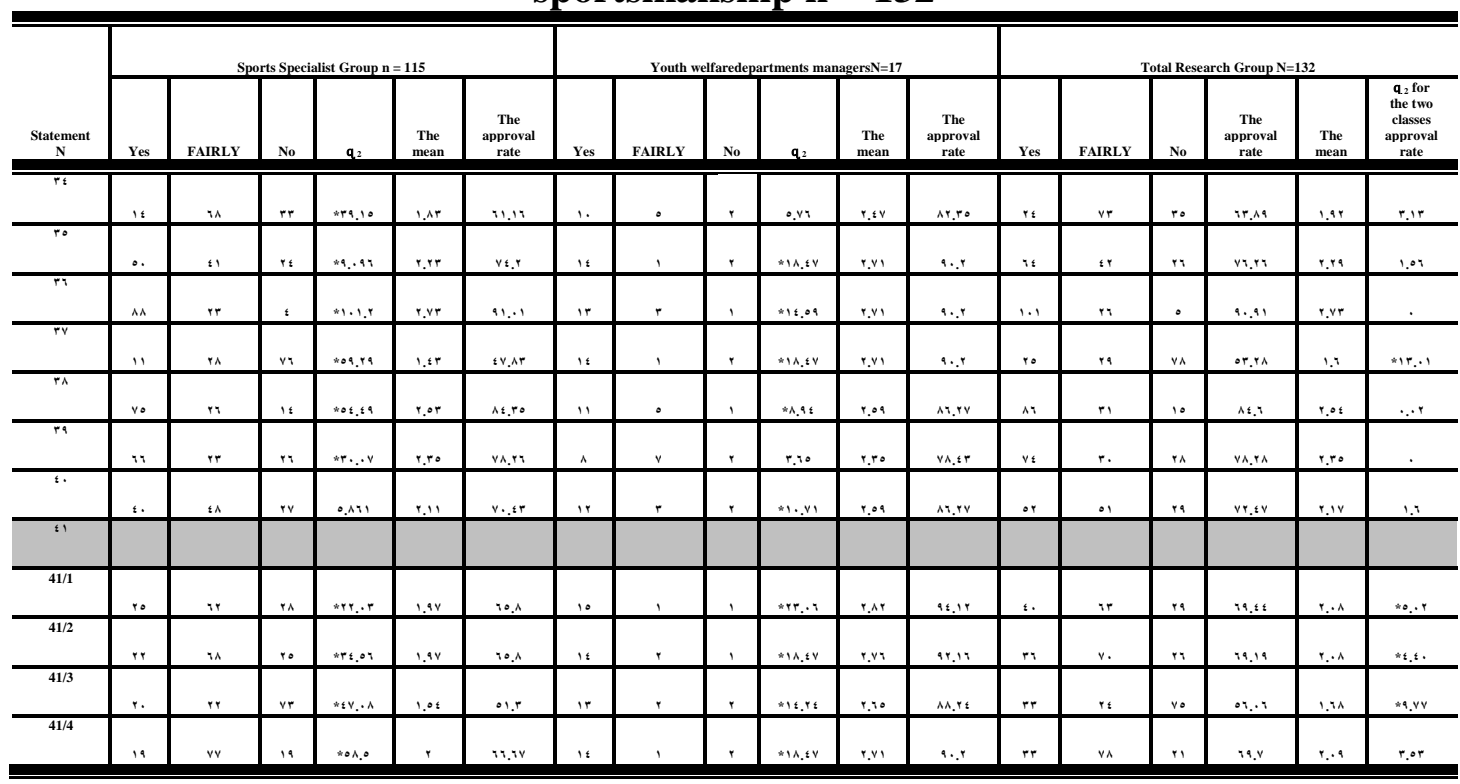

- $\quad \mathrm{q}_{2}$ significant WITH $0,05=5,9$ 
Illustrated by table (9) search sample consensus on phrases numbers $(41 / 1,41 / 2$, 14/4) where squared value of approval categories (3.13:5.02) by consent of medium ranged between College Research Group (63.89:69.19\%) There are fairly consultation between specialists, , sports activity Manager is keen not to youth wellfare University of Alexandria to encourage specialists, athletes on entrepreneurship and creativity within work enough to not discuss ideas and proposals from all professionals athletes, professional sports are not appreciated for its contributions in continuous

ALaa Alsayed (2010) indicates that we need to demonstrate the ability of the Administration to encourage creators and provide an appropriate environment to work better. (4:109)

the two researchers stress the need to create awareness and awareness of sports specialists, of the matrix citizenship by encouraging its practice to discuss all ideas and proposals issued by specialists. The research sample agreed on phrases of numbers $(35,36,38$,
39, 40) where Q2 value of approval categories ranged between $(0.00: 1.6)$ refers to try to develop athletes specialists working performance rates that serve the achievement of objectives, volunteer in providing solutions to the problems facing the Department of sports activity, their eagerness to optimal use of labour resources.

Mohammed Jalal Soliman (2001) (20), Yilmaz, K. \& Tasdan, M, (2008) indicate that we need to avoid problems associated with work and initiative to provide innovative solutions. (44:112).

While the phrases numbers $(37,41 / 3)$ where Q2 value of approval categories $\quad(9.77 *$ : $13.00 *)$ by specialist consent athletes (47.83:51.3\%) And the percentage of approval of Directors (88.24:9.02\%) Refer to the sports specialist frequency any action that contributes to improving the image of the work, not to give them a space of freedom in performing their

Rajab Hussein Rifai (2004) (25) assured: to build a climate of mutual trust with employees by giving them a space of freedom to perform their duties 
Table (10)

approval of the second axis dimensions: the fourth dimension:

conscience awareness $n=132$

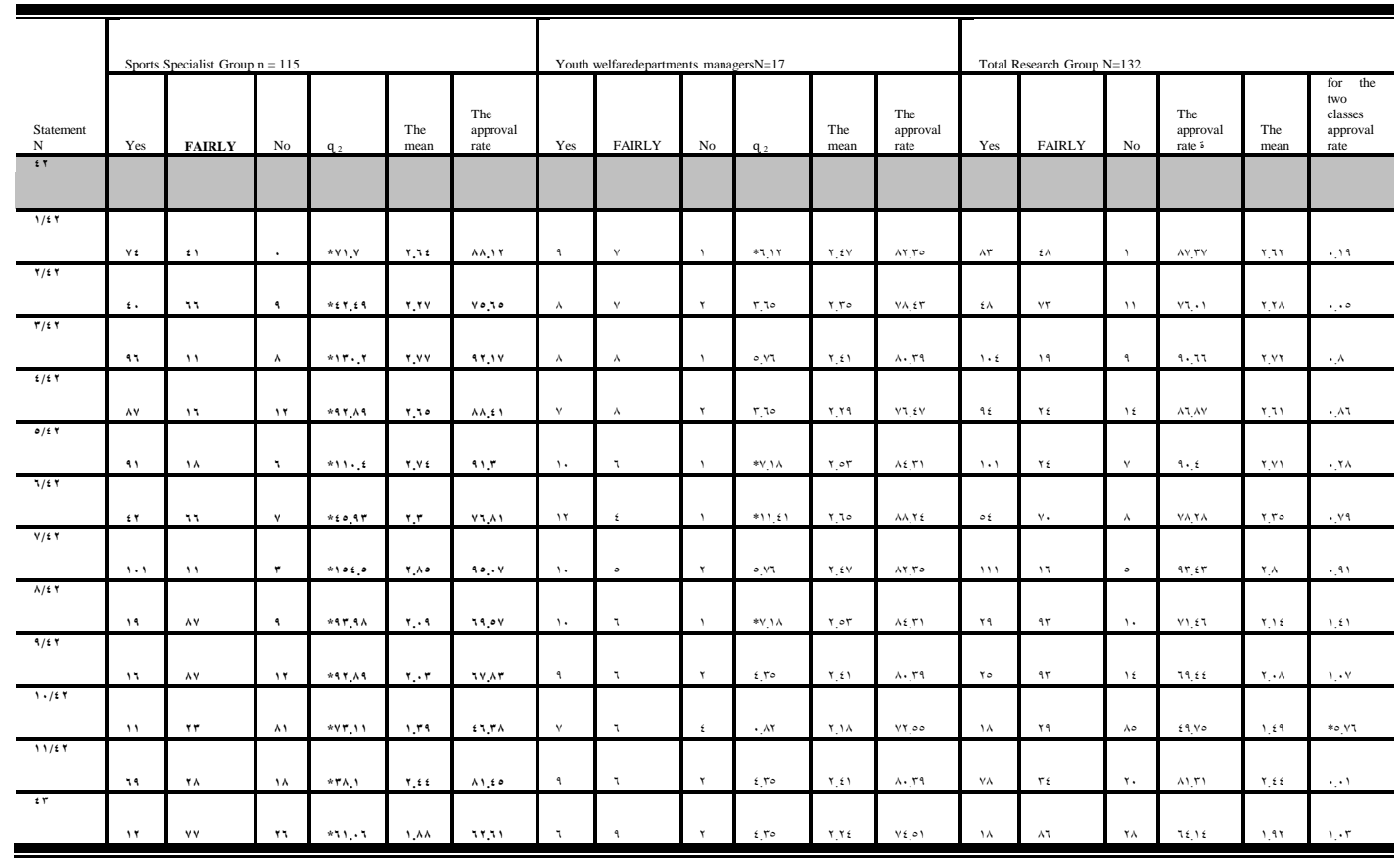

$\mathrm{q}_{2}$ significant WITH $0,05=5,99$

Illustrated by table (10) there is no moral difference

sincerity and honesty, commitment to ethics. between search phrases categories responses (42/1:42/7, 42/11) and approval of the Faculty ranged between (76.01:95.44\%) Which indicates a keen sports specialists follow the regulations and norms, spend most of the working hours in the functional duties, abide by the dates of attendance, precision work, identifying work problems with all

The results of Mohamed Galal Suliman (2001) (20) study confirm the individual conscience awareness beyond the official role and requirements such as unpaid overtime work, strictly follow the regulations. The two researchers due to feeling all sports specialists and sports activity management managers organizational justice is 
reflected on the exercise of citizenship behavior.

While there was consensus among respondents with an average rate of about phrases $(42 / 8,9 / 42,43)$ by consent of faculty ranged between (64.14:71.46\%) Not enough athletes specialists keen to achieve objectivity in identifying problems, lack of all the facts to make a decision within the work.

Sherifa Fadel

Muhammad study (2014) (30) recommended that the importance of behaviors affect heads values of loyalty and citizenship of employees through powerless their career

\section{Table (11)}

ratio of approval to the second axis dimensions phrases: the fourth dimension: civilly $n=132$

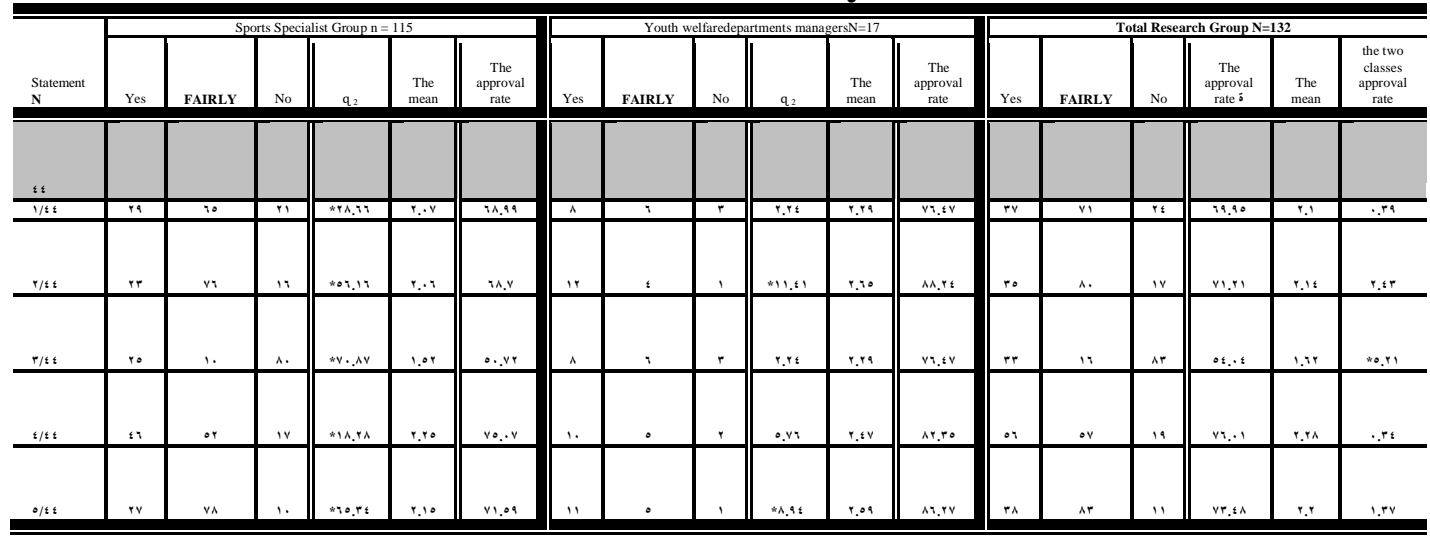

- $\quad \mathrm{q}_{2}$ significant WITH 0,05=5,99

Shown in table (15) search sample consensus on phrases numbers $(44 / 1,44 / 2$, $44 / 4,44 / 5)$ by consent of faculty ranged between (69.95:76.01\%) To ensure that the sports specialists consult with each other in case of taking any decision, following all the activities carried out by the Department of sport activity, the commitment to attend official meetings and symposia proposals which in turn contributes to the development of work methods. Buk Hari (2008) mentioned that civility is one of 
citizenship, which is one of the characteristics of the informal meetings and seminars. (36:107)

The two researchers believe that civility is the specialist attention athletes exchanged views with colleagues and consulted in case of decision-making.

While the search categories had divergent views about the term (44/3) were the youth welfare departments managers approval percentage $(76.47 \%)$, While the opinions of sports specialists, $(50.72 \%)$ ka2 to the approval categories (5.21) not keen to attend events and athletes specialists seminars informal sports activity management Yilmaz, K. M, Tasdan \&, (2008) indicated that the importance of constructive participation and contribution to attend meetings and seminars. (44:120)
The two researchers believe that the degree of integration of sports specialists in action a moral effect on the degree of job performance, the individual's sense of justice contribute to high organizational citizenship behaviors. 
Table (12)

correlations between organizational justice and citizenship for youth welfare departments athletes Alexandria University $n=132$

\begin{tabular}{|c|c|c|c|c|c|c|c|}
\hline & \multirow[b]{2}{*}{$\begin{array}{l}\text { Correlation } \\
\text { coefficients }\end{array}$} & \multicolumn{6}{|c|}{ Organizational citizenship behavior } \\
\hline & & First & Second & Third & Fourth dimension: & Fifth & $\begin{array}{l}\text { Total axis 2: o } \\
\text { Rganizationa }\end{array}$ \\
\hline \multirow{4}{*}{ 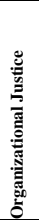 } & $\begin{array}{l}\text { First dimension: } \\
\text { distributive justice }\end{array}$ & $* * . \leqslant$ ro & $* * . \leq .9$ & $* *$. orr & $* * \cdot . \Lambda \mathrm{r}$ & $* * \cdot$ rTV & $* * . . \leqslant r$ \\
\hline & $\begin{array}{l}\text { Second dimension: } \\
\text { procedural justice }\end{array}$ & $* * .091$ & **. Or. & **. $T$ TIV & $* *, \operatorname{TTV}$ & $* * ., \ldots$ & $* * .7 \leqslant$. \\
\hline & $\begin{array}{l}\text { Third dimension: } \\
\text { interactive justice }\end{array}$ & $* * .000$ & $* * . \leq \leqslant 7 \leqslant$ & $* * .717$ & $* \cdot, r+1$ & $* * ., r \cdot r$ & **. $\cdot T / 4$ \\
\hline & Total axis 1: organizational justice & $* *$. or. & $* * .0 .4$ & . & $* * . \leqslant 1$ & $* *, r \leq r$ & $* * \cdot . T r \wedge$ \\
\hline
\end{tabular}

$* * " r$ "value significant with $0,01=0,228$

* Significant with $0,05=0,174$

Illustrated by table (12) there is a direct correlation between the moral dimensions of organizational justice and citizenship behavior dimensions where the value of the correlation coefficient between them (0.628), in the light of the above it is clear that the order of organizational justice dimensions according to the degree of organizational citizenship behavior link is as follows first procedural justice correlation (0.640), II interactive justice total correlation (0.612), III distributive justice attained (0.483)

The results of a study confirm Adel Mohammed Zayed (2000) (2) that there is a positive relationship between organizational justice and organizational citizenship behavior components. The two researchers confirms that the organizational citizenship behavior demand a lot of public organizations and private sports organizations because of the positive effects that improve performance and increase effectiveness

\section{The results:}

The first axis of organizational justice:

-The functional tasks are not distributed equitably among the sports specialists

-No sense of Justice in the promotion system approach to managing youth sports activity sponsored by the University of Alexandria.

- Not having enough freedom for the sports specialists to 
choose the manner of implementation of the work assigned to them

Axis II: citizenship behavior: 1. The unwillingness of specialists, athletes to work extra hours voluntarily.

2 . No keen Director of sports activity sponsored by the Alexandria University youth wellfare to encourage athletes specialists on entrepreneurship and creativity in work.

3. Not to give sports specialists space of freedom in performing their business the way they see it.

4. Not to keen on sports specialists acknowledge any mistake they may have.

5. Not to keen sports specialists in the sports activity management specialists to attend meetings and seminars informal sports activity management.

\section{Recommendations:}

1. The need to develop and increase the awareness of managers managing physical activity youth welfare departments of the three types of organizational Justice (distributive, procedural, dealing) reflected positively on the performance of specialists and practitioners affect their behavior and their ability to complete the work assigned to them

2. The importance of achieving justice and equality in the distribution business and burdens, rewards and incentives because of its positive impact on achieving contentment and satisfaction than specialist urges specialists to perform their tasks effectively with youth welfare departments, University of Alexandria

3. The need for training courses for various levels of management to realize citizenship and its role in supporting organizational justice

4. Encourage innovative proposals for the first stage of the initiative and voluntary behaviors which help develop..

\section{References:}

\section{Frist: Arabic References:}

\section{Abdul Karim Saleh} al-Sokar (2013): "Impact of procedural justice in job performance in the ministries of Jordan", Administrative Sciences Studies Journal, Vol. (40), University of Jordan.

$2 . \quad$ Adel Mohammed
Zayed (2000): "Citizenship
behavior development in the


Egyptian business section", Accounting, administration, and insurance magazine, Faculty of Commerce, Cairo University.

3. Adel Mohammed

Zayed (2006): "Organizational justice for human resources management",

Arab

Administrative Development Organization (ARADO), Cairo. 4. Alaa Mohamed Sayed (2010): "Administrative leadership and innovation management", Dar Al Fiker Publishers \& Distributors, Jordan.

5. Alia Hosni Aladdin Noah (2013): "Impact of organizational support corporate performance and organizational citizenship behavior", Master Thesis, Faculty of Business, Middle East University, Jordan.

6. Amer Ali Hussein alAtwi (2007): "Impact of organizational justice in the contextual performance of members of the teaching staff at the School of Management and Economics", University of Al-Qadisiyah, Iraq.

7. Amin Abdul Aziz Hassan (2001): "Business Administration and challenges of the new century", Dar Qubaa for publication, Cairo.

8. Barzan Saber Hossain (2014): "Requirements for achieving organizational justice for performing career Mozivy activity sports departments at universities Kurdistan - Iraq, Master Thesis, University of Alexandria.

9. Donia Mohammed Adel (2001): " Pressures of work and its relationship with job satisfaction among workers at the University of Alexandria public administration ", Master Thesis, Faculty of Physical Education for Girls, Alexandria University

10. Hakem Mohammad Mohsen al-Rubaie, Haider Hammoudi Aly (2009): "The relationship between organizational justice and alienation functional testing", published master thesis, Faculty of Administration, University of Kufa.

11. Hamid Saeed Shaaban (2010): "Impact of the individual relationship with his boss and awareness of the organizational support of the relationship between justice and organizational citizenship behavior", Faculty of 
Commerce,

Al-Azhar

University.

12. Hamza Mammeri, Zahi Ben Mansour (2014): "Organizational citizenship behavior as a tool for organizational effectiveness in modern organizations", University of Ghardaia, Algeria.

13. Hayan

Hamdan (2015): "Study of the relationship between organizational behavior and effective organizations",

AlWataniya.Private.University, Syria.

\section{4.}

Mahmoud

Abdul

Rahman Ibrahim (2006):

The impact of organizational climate on the performance of human resources in the Gaza Strip", Master Thesis, Faculty of Commerce, Islamic University of Gaza.

\section{Mohamed Abdel-} Hamid Tabola, Ramadan Karim Saad, Ibtisam Ali Hamza Al Abbar (2015): "Sense of justice and organizational citizenship behavior and its relationship to the faculty members in Benghazi", Second issue, University of Benghazi.
16. Mohamed Naguib Mahmoud (2004): "Workers' attitudes towards the realization of the dimensions of job satisfaction in the health sector in Sharkia", Studies and Research business Journal, Faculty of Commerce, Banha.

\section{Mohamed Naguib} Sabry (2004): "Analysis of the determinants that affect the perception of managers for the exercise of citizenship behaviors", Journal of research and business studies, Zagazig University

18. Mohammed Abdul Latif Al Khalifa (2009): "Determinants of volunteering organizational behavior in public organizations", Arab Journal of Administrative Sciences, Vol. V.

19. Mohammed Ahmed Younis

(2009):

"Administrative mistakes and ways to treat youth welfare departments", Master Thesis, Faculty of Physical Education for Boys, Alexandria University.

20. Mohammed Jalal Suleiman (2001): " Tracking the impact of organizational citizenship on moral decision making", scientific journal of 
trade, Vol. (2), Tanta University.

21. Nazik Mustafa Simbel, Yousria Ibrahim Musa (2008): "Relationship between objective evaluation of job performance and the current organizational justice for workers in youth centers in Alexandria system", Journal of Contemporary Education, Cairo.

22. Omar Awad (2003): "Analysis of the organizational justice dimensions", Commercial Research Journal, Faculty of Commerce, January, Cairo.

23. Omar Mohammed Dora (2008): "Organizational Justice and its relationship with some contemporary management trends", Dar AlRadwan, Cairo.

24. Rabin Hamad Rasul (2014): " Obstacles to the regulatory process in youth centers in Erbil governorate Kurdistan Region of Iraq", Master Thesis, Faculty of Physical Education for Girls, Alexandria University

25. Rajab Hussein Rifai (2004): "Study on the determinants of influence and trust between subordinates and their relationship to the behavior of the president of citizenship", Faculty of Commerce scientific journal, Assiut University.

26. Rashid Shabib Ajami (2002): "Analysing the relationship between loyalty and the workers sense for justice and regulatory" , Institute of Public Administration, Muscat.

27. Safaa Mohammed Ammar, Nawal Mahmoud alNadi (2013): " Relationship between the head of the intellectual and organizational citizenship behaviors", Commercial Research Journal, Faculty of Commerce, Sohag University.

\section{Shaaban Hussein Sisi} (2005): "Ability of some organizational characteristics to predict the behavior of organizational citizenship", Faculty of Commerce Journal, Vol (2), Tanta University.

29. Shaima Mohammed Jaber (2014): " Regulatory input and its relationship to achieving the goals of physical activity at the University of 
Alexandria", Master Thesis, Faculty of Physical Education for Girls, Alexandria University.

30. Sharifa Mohamed Fadel (2014): "Effect on the development of citizenship in the Egyptian political systems", Faculty of Commerce Journal, Vol (51), Alexandria University.

31. Yasser Fathi alHindawi Mahdi (2006): "Organizational justice and teachers' performance of citizenship behavior in secondary schools in Egypt", Ph.D. thesis, Ain Shams University, Faculty of Education.

\section{Yousria Ibrahim}

Musa (2007): "Relationship between some of the variables associated with the working climate and the practice of the organizational citizenship behavior on school management in Alexandria", Alexandria University.

33. Yusuf Abdul Atiyah Bahr, Ayman Sulaiman Abu Sweireh (2010): "Impact of organizational climate on the job performance of employees at the Islamic University in Gaza", Periodical human studies, Palestine

Second: Foreign References:

34. Ball , S.,\& Menguc ,B., (2002): The employee organization relashionship , organizational citizenship Behavior and superior service Quality, Journal of Relating , V. 78

35. Bolino , M.C. Turnley, W,H. , And blood Good ,JM ., (2002): Citizenship Behavior And the creation of social Capital in oragazations, The Academy of Management Review , V. 27 , N.,4

36. Bukhari , Z.U.,(2008): Key antecedents of organizational citizenship behavior (OCB)in the banking sector of pakistan, International Journal of business and management, Vol. (3), No.12

37. Gary Dessler(2005): Human Resource Management , Op. Cit.

38. Gill and, S.,Benson, L., and Schepe ,D ., A(2008): Resource management for the hospitality industry, NEW YORK. 
39. Gillil and, S.,Benson, L., and Schepe ,D ., A(2008): Rejection Threshold in Justice evaluation effect on Judgment and decision making.

40. Kalleberg , A, Appalboun, E. Sleigh , S, Schnitt, J(2004): For better or worse : union and Company Trust and Citizenship Behaviors Paper Presented at industrial relation research Association, C.A, January.

41. Niehoff, B. and Moorman, R., (2000): Justice as a Mediator of The Relationship Between Methods of Monitoring and Organizational Citizenship Behavior, Academy of Management Journal Vol. 36, No. 2.
42. Podskoff , P., et al. , (2000): organizational Citizeship Behavoir ; A critical Review of the theoretical and Empirical Literature and suggestions for future Research , Journal of Management ,Vol .26

43. Podskoff , P.,M, Mackenzie, S: Moorman , R, H ., (2002): “ Transformationl Leader Behaviors And Their Effects On Trust, Satisfaction And Organizational Citizenship Behaviors " The Leader Ship Quarterly .

44. Yilmaz , K. \&Tasdan, M(2008):" Organizational citizenship and organizational justice in Turkish primary schools ", journal of educational administration, vol .(47), No. (1). 